\title{
Identification of Causes and Effects of Poor Communication in Construction Industry: A Theoretical Review
}

\author{
Yaser Gamil a*, Ismail Abdul Rahman ${ }^{\mathrm{a}}$ \\ ${ }^{a}$ Faculty of Civil and Environmental Engineering, University Tun Hussein Onn Malaysia, Johor,86400, Malaysia
}

\begin{abstract}
Construction industry is characterized in nature as complex, fragmented, dynamic and involves many parties therefore effective communication is essential to overcome these challenges. Many researchers found that the industry faces major challenge to ensure effective and successful communication throughout the lifecycle of the project which therefore resulted to project failure. Poor communication in construction industry had been addressed in previous research studies; however, this paper presents and examines the identification of causes and effects which lead to poor communication. Further investigations on previous literature were conducted to extract the causes and effects which contributed to poor communication in construction industry. Similarity technique was applied to avoid duplications in the identified causes and effect of poor communication. Using the frequency technique, from the 33 causes of poor communication it was found that the most dominant cause is lack of effective communication. Whereas, out of 21 effects from poor communication, it was found that highly repeated effect is time overrun. These findings will serve a good platform for further investigation on the relevancy of causes and effects to the local construction practitioners.
\end{abstract}

\section{Keywords:}

Causes;

Effects;

Poor Communication;

Construction Industry.

\section{Article History:}

Received: 25 September 2017

Accepted: 10 December 2017

\section{1- Introduction}

Construction industry defers from other industrial sectors by its distinctive characteristics and structures [1]. It is an expandable and complex sector in which it develops over time to accommodate and shelter the rise of population number it also involves many parties from public and private sectors [2, 3]. These characteristics have resulted in more complexity and challenge to produce effective, sustainable and acceptable quality products [4]. Amongst these challenges is poor communication among construction teams. Poor communication is described in this context as ineffective, unsuccessful, and deficient and lack communication process of project information which should be avoided in construction industry [5]. As the key aspect to construction project success is effective communication [6, 7].

Poor communication has many effects and consequences in construction industry such as cost overruns, time overruns, dispute and finally project failure. It was proven that unsuccessful communication leads to unproductive outcomes [4].Project Management Institute [8] investigated communication in organization specifically in construction projects and found that by adopting effective communication during the construction of the project it can help in meeting the stipulated goals and objective of the projects. It also found that highly effective communication can achieve better time and cost management in producing successful projects.

Poor communication in the construction workplace can be either in large scale or small scale. Large scale forms between construction parties such as consultant, client and contractor. However, in small scale occurs between individuals in the same firm. It therefore leads to many undesirable consequences either in large scale or small scale. In large scale the effects are much sever in which conflict and failure of the project may occur however between employees it can cause many effects to the work progress, accidents and mistakes during the construction [5].In general, majority of the problems in construction industry are caused by improper and ineffective communication [2]. This study aims at exploring poor communication in construction industry and defining the causes and effects of this phenomenon throughout the lifecycle of the project.

\footnotetext{
* CONTACT: Yaseruthm@yahoo.com

DOI: http://dx.doi.org/10.28991/ijse-01121
}

(C) This is an open access article under the CC-BY license (https://creativecommons.org/licenses/by/4.0/). 


\section{2- Literature Review}

Poor communication in construction industry (CI) has been investigated extensively by many researchers and construction practitioners. It attracted the concern of the studies due to its important in construction industry [7]. It is one of the main causes of project failure [9] subsequently it causes cost and time overruns in the form of rework occurrence [10] and miscommunication among construction parties [11].

There are many forms and practices of poor communication in construction industry. Lack of frequent communication among construction parties is one of the forms of poor communication [12].A comparative study on causes and effects of delay in Nigerian and Iranian construction projects by Oshodi \& Rimaka [13] ranked lack of communication between construction parties from the contactors perspective based on its importance as the 11th and 12th for Nigeria and Iran respectively however the ranks from the consultant perspective were 20th and 13th for Nigeria and Iran respectively. These results confirmed the significance of proper communication in the minimization of time overruns in construction projects.

From another viewpoint, a study conducted by Darvik \& Larsson [14] on the impact of material delivery deviations on costs and performance in construction projects showed that quality defects and delivery deviation of materials occurred due to lack of communication among relevant parties and communication failure. Therefore, it was suggested, stakeholders have to put more concern in the enhancement of communication regularity, means and methods.

Communication skills are essential to produce effective communication however if the speaker lacks of these skills then poor communication may result. Interpersonal skills which include communication skills play an important role for the success of a project [15]. Parties involve in construction possess different communication skills which also depends on their qualification and cultural background. These differences cause concurrent misunderstanding in the delivery stage [16].

In construction industry, communication is managed by channels in all the organizations hence each department or section in the organization is responsible of disseminating the related information to formulate complete communication system However due to the complexity in construction industry several concurrent communication problems occur because no proper channelling is adopted to manage and control the communication process [17]. Lee \& Bernold [11] reported that effective communication in construction is seriously hampered due to a lack of appropriate data channels, improper channel and inaccurate data transfers. Tipili et al [18] stated that, unclear channels of communications result in project delay. It is therefore very important to standardize the channels of communication in construction industry to fasten and ease the communication process.

Dispute is a common issue occurs in construction industry. It causes an impact on the main project components such as cost, time and quality of construction projects [19]. Dispute is commonly known as an endemic and chronic character of construction industry [20]. It was emphasized by many researchers; poor communication among construction industry is one of the main causative factors of dispute occurrence. It is therefore a major consequence of unsuccessful communication. Kumaraswamy, [21] identified poor communication among construction parties as one of the significant causes of dispute. Lack of communication skills is considered of the utmost important diffusing factor to cause dispute in construction industry [22]. Therefore, effective communication is very important to improve the relationship between the project team [23].

Time overrun is also known as delay which is referred as time beyond the completion date assigned in the contract during the inception stage of construction [7, 21].Time overrun is classified as the most frequent problems in construction industry which in return causes adverse effects on the project success [24]. Without proper communication on the objective among stakeholders, it can cause delay [25]. Literatures have revealed that poor communication is one of the main factors contributing to delay in construction [9]. Delay caused by poor communication can be in the form of slow information flow, improper communication channels, wrong design, wrong interpretation, reworks and etc. [7, $18,26,27]$.

Concept of cost overrun in construction industry means that the project failed financially to achieve its objective [9] Cost overrun occurs when project's cost exceeds the contract sum and causing major conflict and litigation which might extremely leads to project abandoned or failure [25]. A study by Alhomidan [28] in Saudi Arabia had identified 41 cost overrun factors in several road construction projects. It was found that, most of critical factors affecting cost overruns are internal administrative difficulties, poor communication among construction parties, payments deferment, and delays in decision making. In another investigation by Bassioni, Sarhan, and Zaki [3], it was found that lack of communication and coordination between design participants of different background recorded higher relative impact to cost overrun in design phase of Egyptian construction industry. This study extends the method of defining poor communication in construction industry by extracting the causes and effects of its existence in the industry. 


\section{3- Methodology of the Study}

In this study, the method adopted is based on systematic reviews of previous literatures. Figure 1 illustrates the basic methods used to carry out this study.

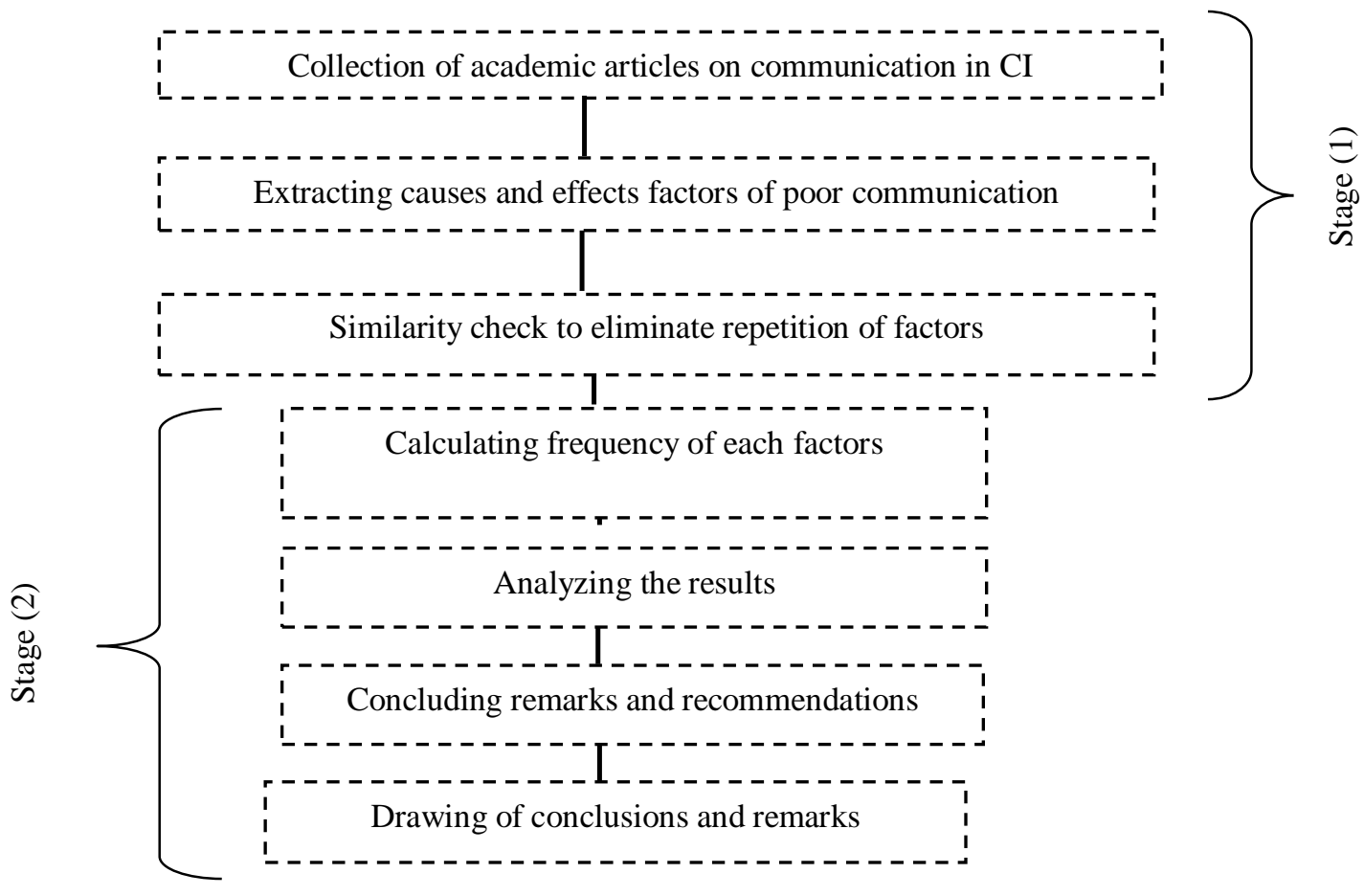

Figure 1. Methodology of the study.

\section{3-1- Literature Search}

Rigorous investigation on previous literatures was carried out to extract the factors related to causes and effects of poor communication in construction industry. A total of more than 57 numbers articles which are associated with the subject of poor communication in construction industry were analysed and scrutinized to identify the causes and effects of poor communication in construction industry. These articles are basically academic and published documents.

\section{3-2- Similarity and Frequency Analysis}

Based on these articles, causes and effects factors were extracted randomly and then these factors were analysed using similarity checking and frequency analysis. Similarity analyses were performed to eliminate any repetition of any factor which has different phrase or synonyms and similar concept. Frequency analysis is a count of repetition of each factor appeared in different literature sources. This analysis is an initial assessment on the most recurring and repeated factors occurred in different literature and different construction projects to determine the level of significant of each factor. Table 1. shows an example of similarity analysis of one factor. It is obvious that, the factor existed in different academic articles with different phrases but carries similar meaning therefore a general term has to represent all the factors that satisfy the meaning.

Table 1. Illustration of Similarity Analysis.

\begin{tabular}{lcc}
\hline \multicolumn{1}{c}{ Causative Factors From Previous Studies } & References & Accepted Causative Factors \\
\hline Lack of good communication mechanisms & {$[9,12,29]$} & $\begin{array}{c}\text { Lack of effective communication } \\
\text { system and platform }\end{array}$ \\
Lack of uniform standards for construction information & {$[12,30]$} & \\
Lack of communication system & {$[7,11,12,29,30,31,32]$} \\
Ineffective reporting system & {$[7,32,33]$} \\
Lack of feedback system & {$[33]$} \\
lack of appropriate data channels & {$[7,11]$} & \\
\hline
\end{tabular}




\section{4- Result and Discussion}

In this study, an intensive investigation of academic articles which focused on the causes and effects factors of poor communication in construction industry therefore to understand the concern of researchers over the past 25 years it is important to demonstrate the development of studies of communication in construction industry.

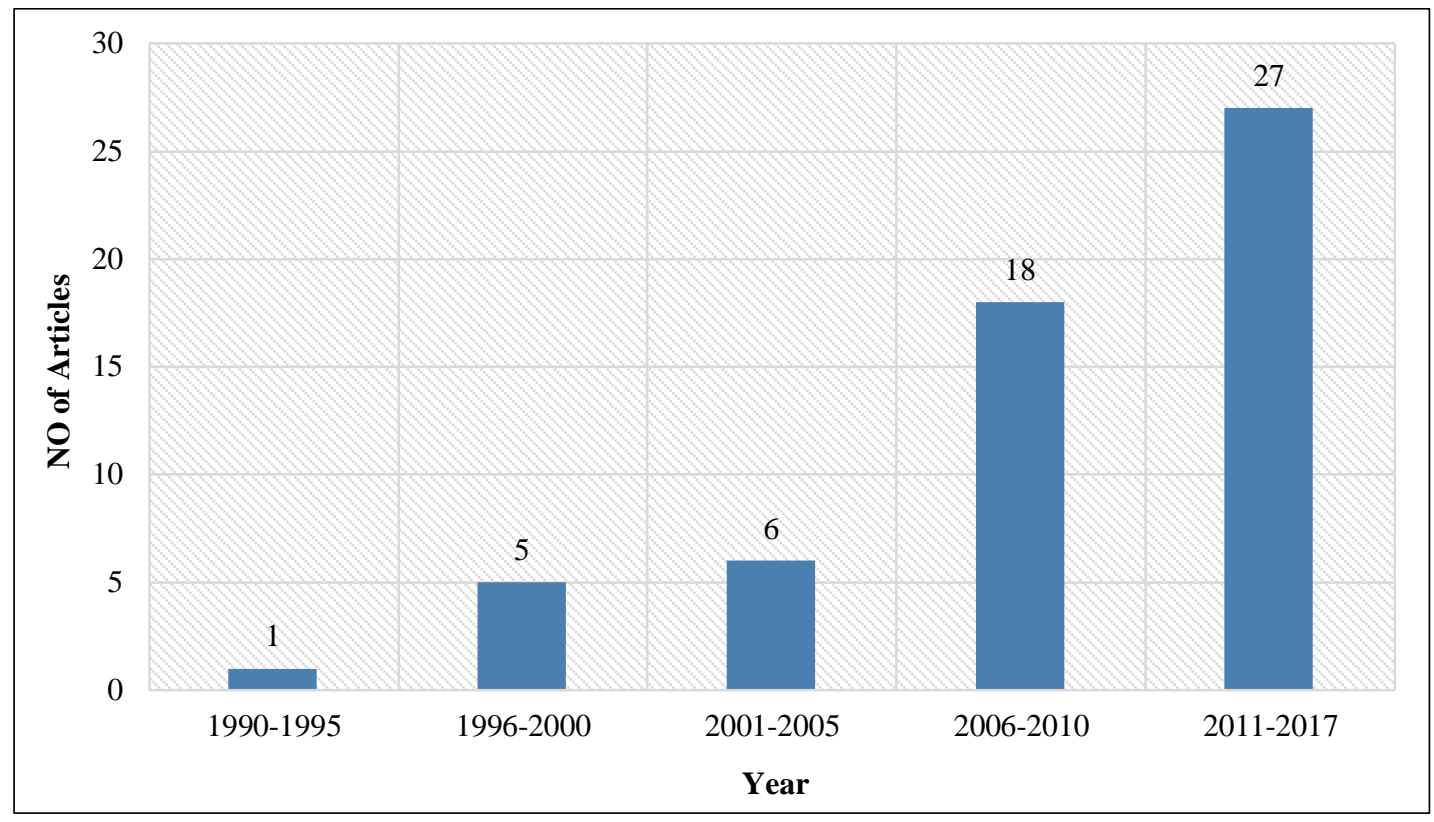

Figure 2. No of Articles on Poor Communication in Construction Industry.

Figure 2. shows the number of articles focusing on causative factors effects of poor communication in construction industry over the past 25 years. It is obvious that there are gradual increments over 26 years started from 2011 to 2017 on the studies of communication in construction industry and this indicates that more concern on communication is required in line with the expansion of construction industry worldwide.

In the following section, a tabulated findings of causes and effects factors of poor communication in construction industry are introduced to investigate the significance and the frequency of each factor. This helps draw a clear understanding of each factor and its significance to causing the problem.

Table 2. Matrix of Causative Factors of Poor Communication and Their Frequencies.

\begin{tabular}{|c|c|c|c|}
\hline \multicolumn{2}{|c|}{ Causative Factors } & \multirow{2}{*}{$\begin{array}{l}\text { References } \\
{[7,9,10,11,15,16,21,23,27,29,34,35,36,} \\
37,38,39,40]\end{array}$} & \multirow{2}{*}{ Frequency } \\
\hline 1) & Lack of effective communication between construction parties & & \\
\hline 2) & Lack of effective communication system and platform & {$[7,9,11,12,21,23,29,31,32,33]$} & 10 \\
\hline 3) & Poor communication skills & {$[3,7,10,12,, 27,29,38,39,41]$} & 9 \\
\hline 4) & Language barrier & {$[7,10,15,27,42,43,44]$} & 7 \\
\hline 5) & Improper Communication channels & {$[7,11,12,27,30,42]$} & 6 \\
\hline 6) & Possessing different level of education among construction teams & {$[7,10,16,42]$} & 4 \\
\hline 7) & Lack of support for advanced communication technologies & {$[7,10,16,42]$} & 4 \\
\hline 8) & Diversity of culture and ethics among construction teams & {$[10,15,27,42]$} & 4 \\
\hline 9) & Personal barrier & {$[7,10,42,45]$} & 4 \\
\hline 10) & Technology malfunction & {$[7,12,16]$} & 3 \\
\hline 11) & Possessing differed skills levels among construction teams & {$[10,15,16]$} & 3 \\
\hline 12) & Complexity of the construction industry & {$[7,10,15]$} & 3 \\
\hline 13) & Lack of communication plan & {$[11,12,21]$} & 3 \\
\hline 14) & lack of appropriate communications medium & {$[7,11,32]$} & 3 \\
\hline 15) & Inaccessibility of information & {$[46,47]$} & 2 \\
\hline 16) & Slow information flow between parties & {$[9][45]$} & 2 \\
\hline 17) & frequent changes of project contract & {$[7,29]$} & 2 \\
\hline 18) & improper communication time management & {$[7,10]$} & 2 \\
\hline
\end{tabular}



19) Poor planning and coordination
20) poor communication management
21) lack of clear objectives
22) lack of mutual respect and trust among construction teams
23) Weak organizational structure
24) Inaccurate delivery of project information
25) unavailability of information in the time of need
26) Lack of communication procedure and training
27) contractual barrier
28) lack of adequate representation for project stakeholders
30) Noise interruption
31) Poor detailed drawing
32) Incorrect instructions or technical information

$[7,32]$

2

$[6,7]$

$[7,45]$

2

$[7,46]$

2

[12]

1

[11]

[47]

[46]

[46]

Table 2. shows a list of 33 identified causes of poor communication from previous studies and their repetitions known as frequency which are used to determine individual cause considered by numbers of researchers. In Table 2 , the frequency is meant in the study by the number of repetitions of each factor in different articles. It is shown that, lack of effective communication between construction parties occurred 17 times in different literature following that, lack of effective communication system and platform which has occurred 10 times poor communication skills which occurred 9 times. It is rectified those factors have played significant cause in the phenomenon of poor communication in construction industry. This illustrates the significant need of construction industry to take immediate concern in improving the current state of communication.

Table 3. Matrix of Effects Factors of Poor Communication and Their Frequencies.

\begin{tabular}{|c|c|c|c|}
\hline & Effects factors & Reference & Frequency \\
\hline 1) & Time overrun & $\begin{array}{l}{[23][27][34][36][21][10][9][3][24][49][50][51][35][1} \\
8][52] 53][46][55][56]\end{array}$ & 19 \\
\hline 2) & Conflict among construction parties & {$[7][3][18][16][23][57][58][18][59][60][61][62]$} & 14 \\
\hline 3) & Cost overrun & {$[27][36][50][51][18][16][9][64]$} & 8 \\
\hline 4) & Rework and redesign occurrence & {$[7][10][18][54][26][18][59]$} & 7 \\
\hline 5) & High accident rate & {$[49][18][53][20][57]$} & 5 \\
\hline 6) & Failure of the project & {$[7][21][63][65][66]$} & 5 \\
\hline 7) & Demotivated workforces & {$[7][12][10][18][31]$} & 5 \\
\hline 8) & Poor team work & {$[10][16][18][66]$} & 4 \\
\hline 9) & Late response to disaster & {$[7][51][54][56]$} & 4 \\
\hline 10) & Low productivity & {$[7][18][43]$} & 3 \\
\hline 11) & Misunderstanding & {$[10][16][18]$} & 3 \\
\hline 12) & Misinterpretation & {$[10][16][18]$} & 3 \\
\hline 13) & Design errors & {$[27][18][20]$} & 3 \\
\hline 14) & Low Level of satisfaction among construction parties & {$[27][18][20]$} & 2 \\
\hline 15) & Frequent remedies in design and planning schedule & [7][25] & 2 \\
\hline 16) & Waste generation & [67][64] & 2 \\
\hline 17) & Unclear channels & [7] & 1 \\
\hline 18) & Poor risk management & {$[18]$} & 1 \\
\hline 19) & Poor project documentation & [57] & 1 \\
\hline 20) & Poor planning & [68] & 1 \\
\hline 21) & Affects design process & [68] & 1 \\
\hline
\end{tabular}

Table 3. shows 21 effects factors resulted from the problem of poor communication in construction industry. It also lists the effects factors of poor communication in construction industry with their frequencies. It is shown that, the most repeated effect is time overrun which appears 19 times previous literatures. Second most effect is cost overrun which 
appeared 8 times. That shows how poor communication can have high negative effects on cost and time overruns in construction industry. It was confirmed that, poor communication among construction parties is considered one of the leading factors to cause cost and time overruns.

\section{5- Conclusion}

It is concluded that, poor communication phenomenon in construction industry is a major issue faced in all the construction industries around the world therefore achieving successful communication is a major challenge in construction industry due to the diversity and changing nature of construction projects. To enhance communication in construction industry, several measures and methods have to be taken to minimize the causes and effects factors. Basically, effects are results of causes hence eliminating the causes can results in zero effects. In this study, the causative and effects factors were identified from literature. Through literature, 33 causes and 21 effects were identified. The most recurring causes were lack of effective communication among construction parties following with poor communication skills. Furthermore, the most recurring effect was time overruns and consecutively cost overruns. The factors identified will be used to carry out a survey to construction practitioners in order to assess their importance and severity toward the occurring of poor communication in construction industry.

\section{6- Acknowledgement}

The authors acknowledge the financial assistance provided by ministry of higher education in Yemen and research supports provided by University Tun Hussein Onn Malaysia.

\section{7- References}

[1] Anna Dubois \& Lars-Erik Gadde "the construction industry as a loosely couple system: implications for productivity and innovation", Construction Management and Economics, (2002) 20:7, 621-631, DOI: 10.1080/01446190210163543.

[2] Kazi, A. S."Knowledge management in the construction industry: A socio-technical perspective". IGI Global. Technology \& Engineering (2005).

[3] Abd El-Razek, M. E., Bassioni, H. A., \& Mobarak, A. M. "Causes of delay in building construction projects in Egypt". Journal of Construction Engineering and Management, (2008)133(11), 831-841.

[4] Teo.W.M “Communication: Information Management in the Construction Industry". University of South Australia. (1991).

[5] Berntzen, P. "Communication and related work problems in the construction industry". University of Texas at Austin. (1988).

[6] Emmitt, S., \& Gorse, C. "Communication in construction teams". Taylor \& Francis. London. (2006).

[7] Dainty, A, Moore, D and Murray, M “Communication in construction: Theory and practice”, Taylor \& Francis, London. (2006).

[8] Press Releases "Project Management Institute (PMI)" more than half of all project budget risk is due to ineffective communications" retrieved from (www.pmi.org).(March, 2013).

[9] Abdul Rahman, I., Memon, A. H., Karim, A., \& Tarmizi, A. "Significant factors causing cost overruns in large construction projects in Malaysia". Journal of Applied Science, (2013) 13(2), 286-293.

[10] Emuze, F., \& James, M. "Exploring communication challenges due to language and cultural diversity on South African construction sites". Acta Structilia, (2013)20(1), 44-65.

[11] Lee, J., \& Bernold, L. E. "Ubiquitous agent-based communication in construction”. Journal of Computing in Civil Engineering, (2008) 22(1), 31-39.

[12] Tai, S., Wang, Y., \& Anumba, C. J. “A survey on communications in large-scale construction projects in China. Engineering” Construction and Architectural Management, (2009)16(2), 136-149.

[13] Oshodi Olalekan, S., \& Iyagba Rimaka “A comparative study on causes and effects of delay in Nigerian and Iranian construction projects”. Asian Journal of Business and Management Sciences .Vol. 3 No. 01 [29-36] (2013).

[14] Darvik, L., \& Larsson, J. “The Impact of Material Delivery-Deviations on Costs and Performance in Construction Projects". Master's Thesis in the Design and Construction Project Management. Chalmers University of technology. Sweden. (2010).

[15] Gunhan, S., Senol, G., \& Dogan, S. Z. "Non-verbal cues: improving communication in construction projects”. American Society for Engineering Education. (2012).

[16] Cheng, Eddie WL, Heng Li, Peter ED Love, and Zahir Irani. "Network communication in the construction industry." Corporate Communications: An International Journal 6, no. 2 (2001): 61-70.

[17] Fichet, H., \& Giraud, L. "How the information flow is processed in project-based companies compared to others and how it affects strategic drift". Master thesis. UMEA school of business .Sweden. (2007). 
[18] Luka Goji Tipili, Patricia Oyiza Ojeba and Muhammad Sa'adiya Ilyasu "Evaluating the effects of communication in construction project delivery in Nigeria". Global Journal of Environmental Science and Technology: ISSN-2360-7955, Vol. 2(5): pp 048-054, June, 2014.

[19] Gebken, R. J., \& Gibson, G. E. "Quantification of costs for dispute resolution procedures in the construction industry". Journal of professional issues in engineering education and practice, (2006) 132(3), 264-271.

[20] Sinha, M., \& Wayal, A. S. "Dispute Causation in Construction Projects". IOSR Journal of Mechanical and Civil Engineering (IOSR-JMCE). (2007).

[21] Chan, D. W., \& Kumaraswamy, M. M. “A comparative study of causes of time overruns in Hong Kong construction projects”. International Journal of project management, (1997).15(1), 55-63.

[22] Loosemore, M., \& Muslmani, H. A. "Construction project management in the Persian Gulf: inter-cultural communication". International Journal of Project Management, (1999)17(2), 95-100.

[23] Adnan Enshassi Jomah Al-Najjar Mohan Kumaraswamy, "Delays and cost overruns in the construction projects in the Gaza Strip", Journal of Financial Management of Property and Construction, (2009) Vol. 14 Iss 2 pp. 126 - 151.

[24] Faridi, A. S., \& El - Sayegh, S. M. "Significant factors causing delay in the UAE construction industry" . Construction Management and Economics, (2006) 24(11), 1167-1176.

[25] Oluwaseun Sunday, D., \& Olumide Afolarin, A. "Causes, effects and remedies of errors in Nigerian construction documents". Organization, Technology \& Management in Construction: An International Journal, (2013) 5(1), 676-686.

[26] Love, P. E., \& Li, H. "Quantifying the causes and costs of rework in construction". Construction Management \& Economics, (2000) 18(4), 479-490.

[27] Sambasivan, M., \& Soon, Y. W. "Causes and effects of delays in Malaysian construction industry". International Journal of project management, (2007) 25(5), 517-526.

[28] Alhomidan, A. "Factors affecting cost overrun in road construction projects in Saudi Arabia". International Journal of Civil \& Environmental Engineering, IJEE-IJENS, (2010)13(3).

[29] Enshassi, A., Al-Hallaq, K., \& Mohamed, S." Causes of contractors' business failure in developing countries: the case of Palestine". Journal of construction in developing countries, (2006) 11(2), 1-14.

[30] Ahuja, Vanita and Yang, Jay and Shankar, Ravi "Web Based Communication for Construction Project Management". In Proceedings World Conference on Accelerating Excellence in the Built Environment. (2006).

[31] Thomas, S., Tucker, R., and Kelly, W. “Critical communications variables.” J. Constr. Eng. Manage., 129, 1, 58-66. (1998).

[32] Bandulahewa, B. K. M. "Effective project communication for construction project managers in Sri Lanka". Master thesis, University of Moratuwa Sri Lanka. (2015).

[33] Nguyen, T. P., \& Chileshe, N. "Revisiting the Critical Factors Causing Failure of Construction Projects in Vietnam". (Doctoral dissertation, Association of Researchers in Construction Management). (2013).

[34] Kasimu, M. A., \& Abubakar, D. I. "Causes of delay in Nigeria construction industry". The Journal of contemporary research in business, 4(2). (2012).

[35] Tumi, S. A. H., Omran, A., \& Pakir, A. H. K. "Causes of delay in construction industry in Libya". In the International Conference on Economics and Administration (pp. 265-272). (2009, November).

[36] Hoezen, M. E. L., Reymen, I. M. M. J., \& Dewulf, G. P. M. R. "The problem of communication in construction”. (Paper presented at the CIB W96 Adaptable Conference, University of Twente). (2006).

[37] Assah-Kissiedu, M., Fugar, F. D. K., \& Badu, E.” Triggers of disputes within the Ghanaian construction industry”. In Proceedings 5th Built Environment Conference (2010, July). (Vol. 18, p. 20).

[38] Mezher, T. M., \& Tawil, W. "Causes of delays in the construction industry in Lebanon". Engineering, Construction and Architectural Management, 5(3), 252-260. (1998).

[39] Doloi, H., Sawhney, A., Iyer, K. C., \& Rentala, S." Analyzing factors affecting delays in Indian construction projects". International Journal of Project Management, 30(4), 479-489. (2012).

[40] Laihonen, H., Vuolle, M., \& Käpylä, J. "Negative Customer Experiences and Intellectual Liabilities in Construction Industry”. In Proceedings of the 11th International Conference on Intellectual Capital, Knowledge Management and Organizational Learning: ICICKM2014 (p. 274). Academic Conferences Limited. (2014, October).

[41] M. Haseeb, LuXinhai, Aneesa Bibi, Qazi Gulam Raqeeb. "A case study on: Importance of Delay Causes in Construction Projects of Pakistan”. Asian Journal of Business and Management Sciences ISSN: 2047-2528 (2012) Vol. 1 No. 10 [94-101], www.ajbms.org. 
[42] Loosemore, M., \& Lee, P. “Communication problems with ethnic minorities in the construction industry”. International Journal of Project Management, 20(7), 517-524. (2002).

[43] Ali, A. S., \& Wen, K. H.” Building defects: Possible solution for poor construction workmanship". Journal of Building Performance, 2(1). (2011).

[44] Waziri, F., \& Khalfan, S. "Cross-Cultural Communication in Construction Industry: How do Chinese Firms Cross the Barriers in Tanzania”. European Journal of Business and Management, 6(13), 118-122. (2014).

[45] Baguley, Phil "Effective communication for modern business". McGraw-Hill, London; New York. (1994).

[46] Khahro, S. H., \& Ali, T. H. "Causes Leading to Conflicts in Construction Projects: A Viewpoint of Pakistani Construction Industry". International Conference on challenges in IT, Engineering and Technology (ICCIET'2014) July 17-18, 2014 Phuket (Thailand).

[47] Thorpe, T., \& Mead, S. "Project-specific web sites: Friend or foe?" Journal of Construction Engineering and Management. (2001).

[48] Aulich, T. "The role of effective communication in the construction Industry: a guide for education and health clients". Australasian Journal of Construction Economics and Building, 13 (4) 92-101. (2013).

[49] Sadi Assaf, Mohammad A. Hassanain and Salman Al-Zahrani X"Causes of Contractors' Failure in Industrial Projects in Saudi Arabia" Research Journal of Applied Sciences, Engineering and Technology 9(3): 158-164, 2015 ISSN: 2040-7459; e-ISSN: 20407467. (2012)

[50] Gidado, Kassim and Niazai, Ghulam "Causes of project delay in the construction industry in Afghanistan”: EPPM2012, University of Brighton, UK, 10-11th September, (2012)

[51] Apolot, R., Alinaitwe, H., \& Tindiwensi, D.” An investigation into the causes of delay and cost overrun in Uganda's public sector construction projects”. In Second International Conference on Advances in Engineering and Technology (pp. 305-311). (2011).

[52] Mydin, M. O., Sani, N. M., Salim, N. A., \& Alias, N. M. “Assessment of Influential Causes of Construction Project Delay in Malaysian Private Housing from Developer's Viewpoint”. In E3S Web of Conferences (Vol. 3, p. 01027). EDP Sciences. (2014).

[53] Al - Kharashi, A., \& Skitmore, M. “Causes of delays in Saudi Arabian public sector construction projects” . Construction Management and Economics, (2009) 27(1), 3-23.

[54] Liao, P. C., Lei, G., Fang, D., \& Liu, W. "The relationship between communication and construction safety climate in China". KSCE Journal of Civil Engineering, 18(4), 887-897. (2014).

[55] Lo, T. Y., Fung, I. W., \& Tung, K. C. “Construction delays in Hong Kong civil engineering projects”. Journal of Construction Engineering and Management, 132(6), 636-649. (2006).

[56] Kikwasi, G. "Causes and effects of delays and disruptions in construction projects in Tanzania". In Australasian Journal of Construction Economics and Building-Conference Series (Vol. 1, No. 2, pp. 52-59). (2013, February).

[57] Cerić, A. "The impact of asymmetric information on communication risk in construction projects". In Engineering Project Organization Conference. Hrvatska znanstvena bibliografija i MZOS-Svibor. (2010, January).

[58] Mitkus, S., \& Mitkus, T. “Causes of conflicts in a construction industry: A communicational approach”. Procedia-Social and Behavioral Sciences, (2014)110, 777-786.

[59] Gould, N. "Dispute resolution in the construction industry: an evaluation of British practice". Thomas Telford. (1999).

[60] Zulch, B. G. "The Construction Project Manager as Communicator in the Property Development and Construction Industries". Doctoral dissertation, University of the Free State. (2012).

[61] Jaffar, N., Tharim, A. A., \& Shuib, M. N. "Factors of conflict in construction industry: a literature review". Procedia Engineering, (2011)20, 193-202.

[62] Moura, H. M. P., \& Teixeira, J. M. C. "Managing stakeholders' conflicts. Construction stakeholder management", 286316.Chinyio, E., \& Olomolaiye, P. (Eds.) John Wiley \& Sons. (2010).

[63] Dingsdag, D. P., Sheahan, V. L., \& Biggs, H. C. "Safety Culture in the Construction Industry: Changing behavior through enforcement and education". In Proceedings Clients Driving Innovation: Moving Ideas into Practice. The Second International Conference of the CRC for Construction Innovation. (2006).

[64] Nagapan, S., Rahman, I. A., \& Asmi, A. "Factors Contributing to Physical and Non-Physical Waste Generation in Construction Industry". International Journal of Advances in Applied Sciences, (2012)1(1), 1-10.

[65] Haslam, R. A., Hide, S. A., Gibb, A. G., Gyi, D. E., Pavitt, T., Atkinson, S., \& Duff, A. R. "Contributing factors in construction accidents". Applied ergonomics, (2005)36(4), 401-415. 
[66] Salleh, N. A., Nordin, N. M., \& Rashid, A. K. A. "The language problem issue among foreign workers in the Malaysian construction industry". International Journal of Business and Social Science, (2012)3(11), 97-99.

[67] Alwi, Sugiharto and Hampson, Keith and Mohamed, Sherif "Waste in the Indonesian construction projects". In Proceedings, the 1st International Conference of CIB W107 - Creating a sustainable Construction Industry in Developing Countries, pages pp. 305315, South Africa. (2002).

[68] Lessio, D., Philip, M., Wynn, D. C., \& Clarkson, P. J. "Communication and design process planning: initial insights from literature and industry interviews". In DS 58-Proceedings of ICED 09, the 17th International Conference on Engineering Design, Vol. 1, Design Processes, Palo Alto, CA, USA, 24.-27.08. 2009. 